\author{
T.L. Ischuk ${ }^{1, *}$, A.S. Baimukhametova ${ }^{2}$ \\ ${ }^{I}$ Research Tomsk State University, Russia \\ ${ }^{2}$ KaragandyuUniversity of the name of academician E.A. Buketov, Kazakhstan \\ 'tana.itl@mail.ru, 2ayagyul@bk.ru \\ ${ }^{1}$ https://orcid.org/0000-0002-7918-592X, ${ }^{2}$ https://orcid.org/0000-0002-7524-0696
}

\title{
The historical experience of reforms of taxation of individuals in Russia and the Republic of Kazakhstan
}

\begin{abstract}
Object:The study evaluates a reasonable logical sequence of actions (stages) from the analysis of the state of the tax system of individuals and making a decision on reform, to the definition of spare options in case of failure.

Methods:The theoretical and methodological basis for writing this article are the works of foreign, Russian and Kazakh scientists in the field of theory and methodology of taxation of individuals.

Results:The relationship between the measures and results of individual tax reforms based on the experience of Russia, Kazakhstan and other countries from 1991 to 2020 in the framework of ten-year cycles ending in crises, and the provisions of the theories of reforms, taxation, and tax regulation of the economy was revealed. An algorithm for implementing reforms is proposed in (figure 1).

Conclusion: The article analyzes the results of reforms of taxation of individuals for the period from 1991 to 2020.On the example of Russia and the Republic of Kazakhstan, taking into account theories of reforms of taxation and tax regulation of the economy.Identified patterns in the periodicity conduct of reforms, good luck and mistakes in their conduct in terms of tax theory, tax regulation of the economy and the theory of reforms. It is proposed to algorithm of carrying of reform of taxation, which can serve as a universal tool for reforming both the entire tax system and its individual elements. The algorithm can serve as a universal tool for reforming both individual subsystems of the state tax system, and for the tax system in general.
\end{abstract}

Keywords: taxes, taxation of individuals, personal income tax, income tax, vehicle tax, land tax, property tax of individuals, tax reforms.

\section{Introduction}

For writing this article, the methods of scientific knowledge were applied: ascent from the abstract to the concrete, observation, induction and deduction, analysis and synthesis, historical and logical comparison. Authors also used methods and procedures of empirical research: economic-statistical and comparative methods.

The scientific novelty of this article consists in the increment of scientific knowledge in the theory and methodological basis of the tax system of individuals, which can be used to develop practical measures that contribute to the improvement of the tax systems of Russia and the Republic of Kazakhstan.

The theoretical and methodological basis for writing this article are the works of foreign, Russian and Kazakh scientists in the field of theory and methodology of taxation of individuals. The result of the research of this article is the following: the relationship between the measures and results of individual tax reforms based on the experience of Russia, Kazakhstan and other countries from 1991 to 2020 in the framework of ten-year cycles ending in crises, and the provisions of the theories of reforms, taxation, and tax regulation of the economy was revealed. An algorithm for implementing reforms is proposed (figure 1). Its novelty is a reasonable logical sequence of actions (stages) from the analysis of the state of the tax system of individuals and making a decision on reform, to the definition of spare options in case of failure. The algorithm can serve as a universal tool for reforming both individual subsystems of the tax system of the state, and for the tax system in general.

The information and experiential base in writing this article was formed by the normative-legal acts of the Russian Federation and Republic of Kazakhstan, regulating the issues of taxation of individuals; data of the Ministry of Finance (MOF) of Kazakhstan, the Federal tax service (FTS) of the Russian Federation, of the state revenue Committee (SRC) MF RK; statistical data of Federal service of state statistics of Russia (Rosstat), the statistics Committee of the Ministry of national economy (MNE cs) RK. Materials of scientific and practical conferences and seminars, scientific articles and monographs on the research problem, and internet resources were used throughout this research.

\footnotetext{
* Corresponding author.

E-mail address: tana.itl@mail.ru
} 
Taxation of individuals originates from ancient times. As the social system developed and became more complex in different countries, the taxation of the population also changed. Science and practice show that social development can occur through evolution, as a process of change, development and the transition of society from one state to another, either revolution, as a radical coup in the entire socio-economic structure of society, leading to a transition from one historically obsolete to more progressive system. But the most preferred method of social development - reforming, because this transformation is aimed at fundamental change, but not destroy the foundations of the socio-economic structure of society. The lack of reforms is that they require large financial expenditures, but for the failure of reforms, nobody is not responsible.

\section{Literature Review}

Consider the reform of the taxation of individuals in Kazakhstan in the framework of the same periods, because the ten-year cycles of economic crisis proceeded in all countries of the former USSR (Union of Soviet Socialist Republics).After the collapse of the Soviet Union in December 16, 1991 Kazakhstan gained independence, having acquired a new status and new opportunities to build a market economy and integrate into the world community. The tax system of Kazakhstan as well as Russia and other former Soviet republics, demanded radical changes. In the Republic of Kazakhstan began the basis of the new tax system began already developed since 1991. The Law "About tax system of the RK" on 24 December 1991, with 43 taxes: 16 state, 10 mandatory taxes and fees, 17 local taxes and fees. As a result, in the unitary state created a three-tier tax system inherent in a Federal state. Instability of the legislation, the presence of multiple taxes and payments made the tax system almost unmanageable and inefficient.

In the system of taxation of individuals, the following changes occur. From 01.01.1991., the changes introduced to the Law of Kazakh SSR (Soviet socialist Republic) "About income tax from citizens, foreign citizens and persons without citizenship" with the progressive and the non-taxable minimum of 600 rubles, and since 01.10.1992 900 rubles. Introduced Law №.1011-XII "About land tax", providing for basic rates per hectare differentiated according to soil quality and intended use. The law "on tax on property of physical persons" from 24 December 1991 №1045-XII, providing for the rate of 0.1 percentage of the inventory value of buildings, with a wide range of benefits for certain categories of citizens. Since 1993, the country moves to a national currency tenge.

Assessing the results of reforming of this period, it should be noted that the tax changes were carried out in the absence of experience, the catastrophic decline in production, liberalization of prices, galloping inflation, a sharp decline in the standard of living citizens(Skorobogatova, A. et al., 2016).. Changes to the legislation were made several times during the year, due to the requirements of the economic situation in the country amid the global economic and financial crisis. However, there was no in-depth analysis conducted by the tax changes. Did not anticipate the consequences of imposing representatives and experts of the IFA (International Federation of accountants), the OECD (Organization for economic cooperation and development) and the transition economy with its taxation system, which had long experience of the application (Buhalkov M.I., 2007).

The main goal of tax reform of this period was the reduction of the tax burden by reducing existing taxes and payments of social protection of the poor; create a single scale of taxation regardless of the source of income (Borbasova, Z.N., Sedlarski, T., \& Bezler, O., 2019).. The system of taxation of individuals of this period include PIT (personal income tax), property tax, land tax, tax on vehicles, tax on acquisition of motor vehicles, state tax, tax from the property passing as inheritance and donations.

\section{Methods}

To evaluate the impact and success of reforms is necessary to observe a number of requirements: to prepare reforms carefully, in advance, to ensure their legitimacy, focus on major changes in public relations, ensure their implementation by the higher authorities. For obtaining sound theoretical conclusions about the current state of the system of taxation of individuals and evaluation of their results in accordance with the requirements of the theory of reforms, taxation and regulation of the economy a comparative analysis of not only Russian but also other country experience since the collapse of the Soviet Union in 1991 to the present (Shapiro, S.A., \& Shilayev, A.V., 2012).. The choice for the analysis of stages of reform of taxation of individuals from 1991 to 2019 due to ten-year cycles, ending with the crises in 1998, 2008, 2018, the first stage from 1991 to 1999;the second - from 2000 to 2009; the third - from 2010 to 2019.

Will hold out a comparative analysis of the reform of the taxation of individuals on the example of Russia and Kazakhstan with similar tax systems, close economic ties, joint projects of interregional cooperation, agreements in different spheres activity and treaties, international organizations to obtain informed conclusions and develop comparable measures for the further development of tax systems. We will identify patterns 
in the periodicity conduct of reforms, good luck and mistakes in their conduct from the point of view of the theory of taxation, tax regulation of the economy and theory of reforms.

The first period begins with the adoption on December, $7^{\text {th }} 1991$ the Supreme Council of the RSFSR (Russian Soviet Federative Socialist Republic) law "About personal income tax "№1998-I, which came into force on January 1, 1992, but was published only in March 1992.

The non-taxable minimum was equated to the applicable statutory minimum wage (SMIC) (in the first quarter of 1992 amounted to 342 rubles., and in the second quarter - 900 RUB.). Instead of multiple scales was introduced a single progressive scale (table 1.) (Oganesyan, A.C., \& Oganesyan, I.A., 2012).

Table 1. Income tax rates on individuals in Russia, established from January 1, 1992.

\begin{tabular}{|c|c|c|}
\hline Income,RUB/year & Income, RUB/month & The tax rate \\
\hline Upto $\mathbf{4 2 , 0 0 0}$ & to 2,500 & $12 \%$ \\
\hline $\mathbf{4 2 , 0 0 1 - ~ 8 4 , 0 0 0}$ & $2,500-5,000$ & $5040+15 \%$ with excess \\
\hline $\mathbf{8 4 , 0 0 1 - 1 2 0 , 0 0 0}$ & $5,000-10,000$ & $11340+20 \%$ with excess \\
\hline $\mathbf{1 2 0 , 0 0 1 - 1 8 0 , 0 0 0}$ & $10,000-15,000$ & $18540+30 \%$ with excess \\
\hline $\mathbf{1 8 0 , 0 0 1 - 3 0 0 , 0 0 0}$ & $15,000-25,000$ & $36540+40 \%$ with excess \\
\hline $\mathbf{3 0 0 , 0 0 1 - 4 2 0 , 0 0 0}$ & $25,000-35,000$ & $84540+50 \%$ with excess \\
\hline over 420,000 & over 35,000 & $144540+60 \%$ with excess \\
\hline Note: Compiled by the authors & \\
\hline
\end{tabular}

After conduct of the denomination in 1997, the income tax rates were adjusted in accordance with the FL(Federal Law) of the RF159-FL of 01.12.1997 - taking into account the denomination of the ruble 1000 times from 01.01. 1998 (table 2) (Oganesyan, A.C., \& Oganesyan, I.A., 2012). in the future, personal income tax rates in Russia were adjusted almost annually as inflation increased.

Table 2.Income tax rates on individuals, established on the basis of the denomination of the ruble in 1000 01.01. 1998.

\begin{tabular}{|c|c|c|}
\hline Income, RUB./year & Income, RUB./year & Thetaxrate \\
\hline to 20000 & to 1667 & $12 \%$ \\
\hline $\mathbf{2 0 0 0 0 - 4 0 0 0 0}$ & $1667-3333$ & $2400+15 \%$ with excess \\
\hline $\mathbf{4 0 0 0 0 - 6 0 ~ 0 0 0}$ & $3333-5000$ & $5400+20 \%$ with excess \\
\hline $\mathbf{6 0 0 0 0 - 8 0 ~ 0 0 0}$ & $5000-6667$ & $9400+25 \%$ with excess \\
\hline $\mathbf{8 0 ~ 0 0 0 - 1 0 0 ~ 0 0 0}$ & $6667-8333$ & $14400+30 \%$ with excess \\
\hline over 100 000 & over 8333 & $20400+35 \%$ with excess \\
\hline Note: Compiled by the authors & \\
\hline
\end{tabular}

In the property taxation of individuals changes associated with the introduction of a tax on property of physical persons (Law of the RF from 09.12.1991 "About tax on property of physical persons"). Payers recognized the owners of objects of taxation, the rate was $0.1 \%$ of the inventory value of buildings, premises, structures. In accordance with the Federal law from 17.07.1999.№168-FL "About modification and additions in the Law of the RF "About the tax to property of physical persons" tax rate on property of physical persons was changed to a progressive scale of taxation (table 3) (Lobanova, T.N., 2015).

Table 3. Rates of tax on property of physical persons, installed with 17.07.1999.

\begin{tabular}{|l|l|}
\hline The value of the property & The tax rate \\
\hline From 300kRUB & Under $0.1 \%$ \\
\hline From 300k RUB to 500k RUB & From $0.1 \%$ to $0.3 \%$ \\
\hline Over 500k RUB & From 0.3 to $2 \%$ \\
\hline Note: Compiled by the authors \\
\hline
\end{tabular}

Transport tax in RF first began to apply in accordance with the decree of the President of the RF dated 22.12.1993, №2270 "About certain changes in the taxation and in mutual relations of budgets of various levels" (Lobanova, T.N., 2015).However, this Decree is not addressed specifically the issues of taxation of individuals.Tax on vehicles levied, depending on engine power. Initially, transport tax rates established in cents depending on the object of taxation and the power of the engine (Baitenizov, D., Dubina, I., \& Azatbek, T., 2018). Since 01.01.1995, in accordance with the Federal law of the RF dated 11.08.1994 g. 
№25-FL"About modification and additions in the Law of the RF "About the tax to property of physical persons, the size of rates of the transport tax was set as a percentage of the minimum wage in force at the date of calculation of the taxKibanov, A.Y. et al., 2013). In addition, the rates of passenger cars not allocated in the separate line (table 4).

Table 4. Dimensions of taxes on the vehicle in $1991-1999$.

\begin{tabular}{|l|c|c|}
\hline \multicolumn{1}{|c|}{ The name of object of taxation } & $\begin{array}{c}\text { The rates of tax } \\
\text { (kop.) }\end{array}$ & $\begin{array}{c}\text { Therate of tax (\%of the minimum } \\
\text { wage on the date of accrual of the tax) }\end{array}$ \\
\hline $\begin{array}{l}\text { Helicopters, airplanes, motor ships each } \\
\text { horsepower, or each kW of power }\end{array}$ & 50 & 10 \\
\hline Yachts, boats per horse power,or each kW of & 68 & 5,6 \\
power & 30 & 6,8 \\
\hline Snowmobiles, motor boats, etc. with each \\
vehicle horsepower, or each kW of power
\end{tabular}

In accordance with the Federal law from 17.07.1999.№168-FZ "About modification and additions in the Law of the RF "About the tax to property of physical persons" was the reformed system of levying tax on vehicles. Instead of solid bets were limits to the size of the tax in percentage of the minimum wage on the date of accrual of the tax.

Tax on vehicle owners was charged in accordance with the Law of the RF dated 18.10.1999. №1759-1

"About road funds" and was identified separately sailing vessel and towed (towing vessels) (table 1.5).

Table 5. The rates for tax on vehicles, installed in 1999.

\begin{tabular}{|l|c|}
\hline \multicolumn{1}{|c|}{ The name of object of taxation } & $\begin{array}{c}\text { The rate of tax (\%of the minimum } \\
\text { wage on the date of accrual of the tax) }\end{array}$ \\
\hline $\begin{array}{l}\text { Helicopters, airplanes, motor ships each horsepower or each kW } \\
\text { of power }\end{array}$ & 10 \\
\hline $\begin{array}{l}\text { Yachts, boats and other vehicle (with the engine power to } \\
100 \mathrm{HP}) \text { per horsepower or each kW of power }\end{array}$ & 5 \\
\hline Sailing vessels having each passenger place & 6,8 \\
\hline $\begin{array}{l}\text { Snowmobiles, motor boats, etc. with each vehicle horsepower or } \\
\text { each kW of power }\end{array}$ & 30 \\
\hline Towed (towing vessels) & 4,1 \\
\hline Water-air vehicle that has no engines, rowing boats, bicycles & 10 \\
\hline Note: Compiled by the authors & 5 \\
\hline
\end{tabular}

Land relations began to be regulated by the law of the RF dated 11.10.1991. №1738-1 "About land payment", which provided for the use of the principles of paid land use in the form of land tax, rent and the standard price of land.

Thus, the first period from 1991 to 2000 has signs of both a revolutionary and reformist nature, since fundamental changes are taking place in the entire socio-economic structure of society, a transition to market relations, to a variety of forms of ownership.At the same time, in the tax sphere are carried out the transformation aimed at fundamental change, but not destroy the foundations already created a new socio-economic structure of society (Pritvorova, T., Tasbulatova, B., \& Petrenko, E., 2018). Radical transformations in the tax sphere are taking place in all countries of the post-soviet space. In the new Russia it is the Law of the RF "About bases of tax system in the RF" of 27 December 1991 №2118-1 and around 20 relevant laws about the main types of taxes that formed the basis of constructing a fundamentally new tax system of the Russian state.

The need for reform of taxation of natural persons in this period was connected with the reform of the entire socio-economic system of the state, resolution of problems of government, including issues of fiscal, socio-economic and tax policy, the formation of an appropriate legal framework.

In November 1998, was officially recognized the fact of a severe systemic crisis, the impoverishment of a substantial part of the population and a reduction in tax revenues to levels that do not cover the minimum necessary expenses of the state(Ashirov, D.A., 2018). 
Estimating the period of reform of the taxation of physical persons from the point of view of the requirements to reform, not to speak about the thoroughness and timeliness of preparation of the reform in terms of breaking the government, the lack of a clear economic strategy, a deep systemic crisis. However, the tax reform was legitimate, which was established in 1991, the laws and regulations in the tax sphere, as amended and supplemented, formed the basis of the first part of the Tax code of the RF adopted 16.07.98. and entered into force 01.01.99.

Taxation of individuals this period included income tax, tax on property of physical persons, the transport tax and land tax.The tax system Russian was characterized by high tax burdens, the undervaluation and tax evasion, the growth of the shadow economy, the illegal export of capital abroad.Practiced the amendments to the laws on taxes for 3 - 4 times per year, which violated the principle of stability.In General, the reform was aimed at major changes in public relations, to ensure implementation of the higher authorities (1.03.1991 №943-1 adopted RF Law "About tax authorities in the RF").

The second stage of reform of the taxation of individuals in Russia from 2000 to 2009 is characterized by the following changes (table 6).

Table 6. Changes in the taxation of individuals in Russia from 2000 to 2009.

\begin{tabular}{|c|c|}
\hline Changes & Result \\
\hline 1 & 2 \\
\hline \multicolumn{2}{|l|}{01.01 .2001} \\
\hline $\begin{array}{l}\text { Introduced flat rate personal income tax at the rate of } \\
13 \% \text { with no minimum non-taxable income. Revoked } \\
\text { privileges for payment of personal income tax mili- } \\
\text { tary personnel and equated persons. }\end{array}$ & $\begin{array}{l}\text { The redistribution of tax revenues of regional budgets. The } \\
\text { increase of revenues from personal income tax in the consol- } \\
\text { idated budget of the regions. The gradual solution of the } \\
\text { problem of formalizing the real incomes of the population. } \\
\text { The increasing inequality in incomes. }\end{array}$ \\
\hline \multicolumn{2}{|l|}{01.01 .2001} \\
\hline $\begin{array}{l}\text { Introduced a unified social tax (UST) instead of con- } \\
\text { tributions to social extra-budgetary funds at the rate } \\
\text { from } 34.5 \% \text { in } 2001 \text { to } 32 \% \text { in } 2004 \text {. }\end{array}$ & $\begin{array}{l}\text { The increasing complexity of tax administration (each con- } \\
\text { tribution was "fixed" for a separate Fund); the decline in the } \\
\text { quality of tax control. The subsidence of the budget of the } \\
\text { Pension Fund of the Russian Federation (RUB } 300 \text { billion in } \\
\text { 2004) due to the reluctance of employers withdraw wage } \\
\text { "from the shadow". }\end{array}$ \\
\hline
\end{tabular}

2001-2005

The introduction of the Land code of 25 October 2001 and Chapter 3, "Land tax" of the Tax code of the RF by 01.01 .2005 . The establishment of cadastral value of land insteadof used area of land as a tax base.

01.01 .2002

The increase in the inventory value of the property of individuals by increasing the conversion rate of the replacement cost of structures, premises and constructions

From 1.48 to 15 . The establishment of rates of tax depending on total inventory cost (under 300kRUBunder $0,1 \%$; from RUB 300 to $500 \mathrm{k}$ - from 0,1 to $0,3 \%$ and over RUB $500 \mathrm{k}$ - from 0,3 to $2 \%$ ). The provision of the rights of LSG (local self-government) bodies to determine differentiation of rates depending on total inventory cost, type of use and other criteria.

01.01 .2003

Replacement of the tax to users of highways and the tax from vehicle owners to the vehicle tax.

01.01 .2003

Cancel of the tax on purchase of foreign currency connects with a low share of the revenues from this tax in the budget and are not comparable to the high
The opportunity to make more equitable withdrawal of the land tax based on land use and rental component. The reduction in the basic rate of PA. The formation of a land market and new social structure of society.

Differentiation value of the property has created the conditions for the implementation of fiscal and regulatory functions of the tax

and the use of raising factors - stimulating function. Significant gap of inventory value of real estate compared to their real cost is justified due to the difficult financial situation the majority of the populatio.

The termination of the arbitration of disputes about establishment of the object of taxation (or revenue received from sales of products (works, services) or the difference between the bid and asked prices of sold goods.

Output of foreign exchange business from the shadows. The alignment of the currency in all banks and exchange offices, a significant redistribution of customer flows in foreign ex- 


\begin{tabular}{|c|c|}
\hline 1 & 2 \\
\hline cost of its administration. & $\begin{array}{l}\text { change transactions. The restoration of the principle of } \\
\text { economy. }\end{array}$ \\
\hline \multicolumn{2}{|l|}{01.01 .2006} \\
\hline $\begin{array}{l}\text { The abolition of the Law of the Russian Federation } \\
\text { from } 1991 \text { "About the tax from the property passing } \\
\text { as inheritance or donation"/ At the same time in } \\
\text { Chapter } 23 \text { of the Russian tax code was amended } \\
\text { imposing a present of the property as a new object of } \\
\text { taxation of incomes of physical persons. }\end{array}$ & $\begin{array}{l}\text { Compensation of losses of budget revenues by expanding } \\
\text { the tax base. Expanded the list of objects of taxation: real } \\
\text { estate, vehicle, shares. Growth of expenses of citizens for } \\
\text { notarial services the donation and inheritance of property. }\end{array}$ \\
\hline \multicolumn{2}{|l|}{01.01 .2008} \\
\hline $\begin{array}{l}\text { Increased the size of the tax deduction property for } \\
\text { new construction or acquisition in the territory of the } \\
\text { RF of housing RUB } 1000000 \text { to } 2000000 \text { billion. }\end{array}$ & $\begin{array}{l}\text { Anti-crisis measures for the revitalization of the housing } \\
\text { market, relief for those who have arrears on mortgages. }\end{array}$ \\
\hline \multicolumn{2}{|l|}{01.01 .2009} \\
\hline $\begin{array}{l}\text { Increased tax deductions for personal income tax. } \\
\text { The amount of income, giving the taxpayer the right } \\
\text { to a tax deduction in the amount of } 400 \text { rubles in- } \\
\text { creased from } 20000 \text { to } 40000 \text { rubles. For taxpayers } \\
\text { with children - from RUB } 600 \text { to } 1000 \text { and the } \\
\text { amount of income from RUB } 40000 \text {. }\end{array}$ & $\begin{array}{l}\text { On the one hand, it is a shortage of the taxes in the budget, } \\
\text { on the other, in conditions of instability, low income of a } \\
\text { significant part of the population, is the creation of favorable } \\
\text { conditions for reducing the tax burden for socially vulnera- } \\
\text { ble layers of population, rectification of ethical vices }\end{array}$ \\
\hline $\begin{array}{l}\text { accrued cumulative total from the beginning of the } \\
\text { tax period, increased to RUB } 280000 \text { (Artyuhova } \\
\text { I.V., \& Gavrilova L.O., 2015). }\end{array}$ & $\begin{array}{l}\text { the existing social and economic inequalities in society, pre- } \\
\text { vention of social conflicts. }\end{array}$ \\
\hline
\end{tabular}

The period from 2000 to 2004 in Russia is assessed as the achievement of a certain socio-economic stabilization. This is a time of high oil prices on the world market, a growth of more than $5 \%$ of the annual average rate of GDP(Gross Domestic Product), significant growth of foreign exchange reserves, reducing the outflow of money abroad. Elimination of the shadows part of the income of the population in connection with the establishment in 2001 "flat" rate personal income tax of $13 \%$, improving tax collection and budget revenues. Introduction in 2001, UST was triggered by the rise of indirect taxation and saving in the shadow wage, employers were forced to pay the single social tax on salaries of their employees.

With the adoption in October 2001 of the new Land code in Russia, officially there was private ownership of land, which contributed to the attraction of investments, formation of land market (Agafonova, M.S., \& Chikisheva, E.Yu., 2017). Tax conversion in a given period can be regarded as balanced, focused on achieving the goals of tax regulation of the economy: broadening the tax base and creating conditions to implement not only fiscal, but also regulating and stimulating functions of taxes from individuals.

The increase in the tax burden of individuals in this period was impossible, because $20 \%$ of the population with a family income of 4000 rubles per month and the subsistence minimum of a family of three in the 5000 RUB. were in absolute poverty $20 \%$ of families having an income from 4 to 6 thousand rubles a month, was on the verge of poverty and misery, 20\% of families having a family income of 6 to 9 thousand rubles, were simply poor, $20 \%$ of families with income from 100 to 130 dollars per month for each member of the family had by the standards of the state statistics Committee, the average level of income. And only $10 \%$ of households had income from 135 up to $\$ 200$ per month for each family member and could be added to the bottom of the Russian middle class (Kibanov, A.Y., Batkayeva, I.A., \& Mitrofanova, E.A., 2013).

The main changes introduced in parts one and two of the tax code of the RF in 2007-2008 were related to the taxation of legal entities in respect of excise duties, valuation of fixed assets, tax regimes.

The financial crisis of 2008-2009 has affected every company and every employee, every family. Enterprises were forced to reduce staff, working day and working week (Borbasova, Z.N., \& Bezler, O., 2018). There was a sharp decline in income, the devaluation of the ruble, the substitution of private capital to the state. At the same time, there has been a revival of entrepreneurial initiative, the substitution of imported goods by domestic devastation of uncompetitive enterprises and the development of more effective and sustainable, increasing level of competition and, consequently, lower prices for some products: gasoline, property and land, blowing bubbles on different markets.

Despite the mixed results of the tax reform, the positive is the fact that in Russia, unlike in the previous period appeared workable, though imperfect tax system. 
As regards the technology requirements of the reforms, at this stage no in-depth analysis conducted by the tax changes, the goals of the reform have not been quantified. Administrative-legal, economic, political, social and other measures to mitigate negative consequences of tax changes were either insufficient or were absent.

The third stage of the reform of the taxation of physical persons from 2010 to 2020 is characterized by the following changes (table 7).

Table 7. Changes in the taxation of individuals in Russia between 2010 and 2020.

\begin{tabular}{|c|c|}
\hline Changes & Results \\
\hline \hline 1 & 2 \\
\hline 01.012010 & \\
\hline
\end{tabular}

Increased size of state duty on a number of legally significant actions: the acquisition of nationality or the exit from it, and the entry or exit from the country; for committed actions when exercising federal assay; for state registration and for committing other legally relevant actions.

01.01 .2010

Increased average rates of the transport tax twice, while retaining the current minimum level of tax rates, with the RF to reduce these rates not five, but ten times. the right permissions to the authorities of subjects of

Strengthening the role of the state duty as a tool to control the demand and supply of public services, significant fiscal in nature. Giving the state duty a regulatory functionby establishing exemptions for certain categories of citizens and public services. The creation of conditions to ensure a balance of fiscal and regulatory functions of the state duty.

Strengthening the fiscal function of the tax for the replenishment of a profitable part of regional budgets. The implementation of the target function of the transport tax spent by the regional road fund for the maintenance, repair and construction of roads.

01.01 .2010

Cancelled the unified social tax (UST), andhave been established insurance premiums, paid by employers from the wage fund at the rate of $26 \%$,of them $20 \%$ to the PF(Pension Fund)of Russia, 2.9\% to the social insurance Fund of the RF, 1.1\% in the FCMIF(Federal compulsory medical insurance Fund) and $2 \%$ in TCMIF(Territorial Compulsory Medical Insurance Fund).

01.01 .2011

The basic transport tax rate for motor vehicles have been reduced twice. Changed the deadline for payment of the transport tax individuals: not earlier than 1 November of the year following the expired tax period.

01.01 .2012

Changed the size of standard tax deductions for personal income tax in the 1 st and 2 nd child from 1000 to 1400 rubles., and for the third and each subsequent child, up to 3000 RUB. The procedure for obtaining the standard deductions for children has not changed (sub. 4 clause 1 of article 218 of the tax code RF). Cancelled the monthly standard deduction for personal income tax in the amount of RUB 400.

01.01 .2012

Implementation of a pilot project for the period from 2012 to 2014 in the Republic of Tatarstan, Kemerovo, Tver, Kaluga regions for the introduction of real estate tax instead of the existing land tax and property individual tax. Developed "Methodological recommendations on determination of cadastral cost of objects of real estate of uninhabited Fund" for tax purposes, approved by the order of Ministry of economic development Russian.
Transition of compulsory social insurance to civilized insurance principles. The strengthening of indirect taxation: insurance premiums are charged to cost of goods, works, services, and paid by the end consumer.

The reduction rate ofrequired an increase in excise taxes on oil products order to avoid a deficit in roadfunds, respectively led to an increase in fuel prices, and as a result - to growth of prices for consumer goods, growth of inflation and decrease in real disposable incomesof citizens.

Social support for individuals with children, stimulation of the birth rate (the population of Russia from 2004 to 2012 decreased by 2,8 million). The complexity of the allocation of benefits to tax agents and the need for the provision of a package of documents for obtaining deductions. The deprivation of the working population minimum deduction of 400 rubles, in the absence of non-taxable minimum.

Analysis of results works to conduct cadastral evaluation real estate and formation the cadastre of real estate has shown the necessity of taking into account factors affecting the cadastral value: technical characteristics of the object of assessment, the prestige of the area, condition of the yard, parking availability etc.; the application of deductions; the use of benefits only one property; the gradual increase of the tax burden within 5 years. 


\begin{tabular}{|l|}
\hline \multicolumn{1}{|c|}{1} \\
\hline 01.01 .2013 \\
\hline Extended the list of incomes exempted from taxation of \\
personal income tax: the treatment costs, additional \\
insurance premiums for accumulative part of labor \\
pension, the payment by the organization or sole trader \\
of treatment of adopted children of workers under the \\
age of 18 years, former employees who have retired in \\
connection with the retirement due to age or disability. \\
\hline 01.01 .2014 \\
\hline Increased amount of property tax deduction on person- \\
al income tax up to 2000000 rubles. Property deduc- \\
tion for expenses on repayment of interest on target \\
loans (credits) for housing is limited in size to no more \\
than 3,000,000 rubles. \\
\hline 01.01 .2014
\end{tabular}

Fleshed out the list of persons recognized as tax agents, when carrying out transactions with securities and financial tools of urgent transactions.

\subsection{1 .2014}

Application of boosting factor in respect of certain categories of passenger cars when calculating the transport tax.

01.01 .2015

A phased transition to 01.01.2020 year all regions of the RF the tax to property of physical persons on the basis of the cadastral value of the property from the date of registration in the unified state register. Provides for the deduction from $20 \mathrm{sq} \mathrm{m}$ apartment, 10 square meters room and $50 \mathrm{sq} \mathrm{m}$ home. Waiver of real estate tax.

01.01 .2015

Changed the procedure of receiving a property deduction according to the personal income tax when selling real estate owned from 3 years to 5 years.

\subsection{1 .2015}

The introduction of a tax Amnesty for individuals who have arrears and debts on penalties and fines formed to 01.01.2015 transport, land and property tax without graduation individuals.

01.01 .2016

Change the limit value of wages for deduction on personal income tax for the child from 280000 to 350000 rubles.From month, when the income of the employee, calculated cumulatively from the beginning of the year and taxable personal income tax rate of $13 \%$ will be more than 350 thousand rubles, the deduction is not available. The increase in deductions for children with disabilities for parents and adoptive parents from 3 to 12 thousand rubles for each child.

\subsection{1 .2017}

Tax introduction on Parking space, recognized as separate species of property. Tax introduction on nonresidential buildings on the garden and suburban areas. The introduction of penalties for not providing infor-
Reducing the tax burden of individuals, the redistribution of health spending, human capital development, support of investment.

Decrease the gap in quality of life between different social strata society, support for low-income families.

Assistance to individuals in real estate acquisition, housing improvement, development of real estate market and mortgage lending market.

Implementation of regulatory and incentive functions of personal income tax.

The improvement of tax control, providing tax revenues to the budget due to the legislative consolidation of income from operations with securities and financial instruments, and the guarantee of payments under securities of Russian issuers.

The implementation of not only fiscal but also regulatory functions of the transport tax. The multiplying factor depending on the value of the vehicle from 3 to 15 million rubles.

The formation of the list of real estate objects, their distribution on the price zones for the cadastral assessment, the creation of a unified system of taxation. The sharp increase of tax on property of individuals. The Inability to independently calculate the tax large expenses in case of challenging the cadastral value of the property.

Suppression of transactions for the resale of real estate; care of the real estate market in shadow (under-invoicing to reduce tax); a significant decrease of the taxable base of personal income tax; the implementation of its regulatory and stimulating functions.

Improving tax administration; the implementation of the principle of economy.

Improvement of legislation in part of taxation of income. The reduction of the amount of the annual income from which personal income tax is; indexation the limit of nontaxable income. The redistribution of budget funds to support socially not protected layers of the population, of children with disabilities. The implementation of the regulatory function of personal income tax

The broadening of the tax base to increase revenues. The increase in the tax burden of individuals. Strengthening of tax control, the education of tax culture of individuals. The Implementation of fiscal and regulatory functions 
The historical experience of reforms...

\begin{tabular}{|c|c|}
\hline 1 & 2 \\
\hline $\begin{array}{l}\text { mation to the tax authorities about the presence of real } \\
\text { estate and vehicles. }\end{array}$ & of the property tax and vehicle tax. \\
\hline \multicolumn{2}{|l|}{01.01 .2017} \\
\hline $\begin{array}{l}\text { The introduction of resort fees in the territory of } 4 \text { re- } \\
\text { gions in the Crimea, Stavropol, Krasnodar and Altai } \\
\text { territories (Malova, I.I., 2016). }\end{array}$ & $\begin{array}{l}\text { The implementation of fiscal and stimulating function in } \\
\text { the resort fee. The preservation and development of inland } \\
\text { resorts, improving the quality of public services. }\end{array}$ \\
\hline $\begin{array}{l}\text { The reduction ratio (to } 1.1 \text { ) to calculate the vehicle tax } \\
\text { related to passenger cars cost from } 3 \text { to } 5 \text { million RUB. }\end{array}$ & $\begin{array}{l}\text { Support wealthy part of the population; the development of } \\
\text { the market of expensive cars. }\end{array}$ \\
\hline \multicolumn{2}{|l|}{01.01 .2019} \\
\hline $\begin{array}{l}\text { To income in the form of dividends equal the differ- } \\
\text { ence between the income received by way of the com- } \\
\text { pany or at its liquidation, and acquisition costs of } \\
\text { shares. }\end{array}$ & $\begin{array}{l}\text { The broadening of the tax base, elimination of gaps in the } \\
\text { tax laws, the implementation of fiscal and regulatory func- } \\
\text { tions of personal income tax. }\end{array}$ \\
\hline \multicolumn{2}{|l|}{01.01 .2019} \\
\hline $\begin{array}{l}\text { A gradual increase in the rate of tax on property of } \\
\text { physical persons, and the transition to a single order for } \\
\text { the determination of the cadastral value from the mo- } \\
\text { ment of making of information in the Unified State } \\
\text { Register of Immovable Property Rights and Transac- } \\
\text { tions. Changes in the composition of objects of taxa- } \\
\text { tion. Introduction of a deduction for certain categories } \\
\text { of immovable property. The realization of the right to } \\
\text { challenge the payer of the cadastral value. The expan- } \\
\text { sion of the list of beneficiaries. The emergence of the } \\
\text { duties payable by the inhabitants of the Crimea. }\end{array}$ & $\begin{array}{l}\text { Improvement of property taxation of individuals, broaden- } \\
\text { ing the tax base, tax increaseamounts and, accordingly, } \\
\text { revenues of local budgets, but the increase in the tax bur- } \\
\text { den of individuals. the Implementation of fiscal and regu- } \\
\text { lating functions of taxes. Availability socio-psychological, } \\
\text { legal, organizational support reform of property taxation. }\end{array}$ \\
\hline \multicolumn{2}{|l|}{01.08 .2019} \\
\hline $\begin{array}{l}\text { Exemption from payment of TIP(the tax to incomes of } \\
\text { physical persons)with material benefit from economy } \\
\text { on percent mortgage vacation. Exemption from pay- } \\
\text { ment of state duty for amendments to the record of the } \\
\text { Unified State Register of Immovable Property Rights } \\
\text { and Transactions in connection with the realization of } \\
\text { the right to mortgage vacation. The size of the corre- } \\
\text { sponding state duty for physical persons amounted to } \\
200 \text { rubles. }\end{array}$ & $\begin{array}{l}\text { Reducing the tax burden, creating conditions for the im- } \\
\text { plementation of the regulatory and incentive functions of } \\
\text { personal income tax. Violation of the principle of stability } \\
\text { (the tax law should not be changed during the year). }\end{array}$ \\
\hline 17.06 .2019 & 17.06 .2019 \\
\hline $\begin{array}{l}\text { The exception of article } 219 \text { of the TC (tax code) of the } \\
\text { RF government the list of drugs, meaning that a social } \\
\text { deduction will be provided on all the medications pre- } \\
\text { scribed by the doctor. }\end{array}$ & $\begin{array}{l}\text { The exception of article } 219 \text { of the TC (tax code) of the } \\
\text { RF government the list of drugs, meaning that a social } \\
\text { deduction will be provided on all the medications pre- } \\
\text { scribed by the doctor. }\end{array}$ \\
\hline 15.04 .2019 & 15.04 .2019 \\
\hline $\begin{array}{l}\text { The introduction of the amendments on transport tax: } \\
\text { cancellation of tax for stolen ones, not taken with the } \\
\text { account and terminated to search not earlier } 2018 \text { cars. }\end{array}$ & $\begin{array}{l}\text { The introduction of the amendments on transport tax: can- } \\
\text { cellation of tax for stolen ones, not taken with the account } \\
\text { and terminated to search not earlier } 2018 \text { cars. }\end{array}$ \\
\hline
\end{tabular}

Analysis of the reforms of the taxation of individuals in a given period shows that the Russian Government is focused on preserving the existing level of tax burden, encouraging investment and the development of human capital by aligning the tax burden on income from different investment types (securities, Bank deposits, asset sales), increasing the size of tax deductions for personal income tax; a phased transition to 01.01.2020 year in all regions of the RF to the tax to property of physical persons on the basis of the cadastral value. A policy of low taxes, optimization of the composition and structure of taxes, individuals, tax burden and rates of individual taxes, and the use of the system of tax benefits can be assessed as a result of the desire of the authorities to fiscal, regulatory and stimulating balance.

In 1995, in the system of taxation of individuals there are significant changes associated with the decree of the President of RK, having the force of law "Abouttaxes and other obligatory payments to the budget" dated 24.04.1995 № 2235. In income taxation of physical persons for the first time made the transition from scheduletaxation to global taxation of incomes of physical persons on the basis of determining aggregate an- 
nual income, introduced the individual income tax (IIT). In accordance with article 29 "In the income tax rate for physical persons" the Decree of the President of Kazakhstan having the force of Law of RK dated April 24, 1995 № 2235 "About taxes and other obligatory payments in the budget" established rates taxable income of individuals (table 1.8)(Tlesova, E. Zhanabaeva, Zh., 2019).

Table 8. Rate individual income tax in the RK in accordance with the decree of the President of Kazakhstan having the force of Law of RK dated April 24, 1995 № 2235 "About taxes and other obligatory payments to the budget"

\begin{tabular}{|l|l|}
\hline The amount of income & PIT \\
\hline 1) up to 15-fold the annual calculated index & 5 percent with the amount of taxable income \\
\hline 2) of 15-fold to 30-fold the annual calculated index & $\begin{array}{l}\text { tax amount of 15-times annual calculation index 10 per- } \\
\text { cent from the sum exceeding its }\end{array}$ \\
\hline 3) from 30-fold to 65-fold the annual calculated index & $\begin{array}{l}\text { the tax amount with a 30-times annual calculation index 20 } \\
\text { percent from the sum exceeding its }\end{array}$ \\
\hline 4) from 65-foldthe annual calculated index and over. & $\begin{array}{l}\text { the amount of tax with 65-times annual calculation index } \\
\text { 30 percent from the sum exceeding it. }\end{array}$ \\
\hline Note: Compiled by the authors
\end{tabular}

Annual calculation index was equal to 9200 tenge (1 ruble at the rate currency exchange set by the National Bank of Kazakhstan was equal to 74,02 tenge).

Period from 1996 to 1998 is characterized by the completion of creature of the sovereign national tax system, adapting it to market economy requirements.

The beginning of the second phase of the reform of the taxation of physical persons from 2000 to 2008 due to the adoption of RK Code "About taxes and other obligatory payments to the budget" dated 12.06.2001, and its introduction into 01.01.2002.

The population of Kazakhstan in 2000-e years are experiencing hard times. Wages below the national average receive $90 \%$ of agricultural workers, $83 \%$ of education, $64 \%$ of the manufacturing industry. The share of working poor (less than $2 / 3$ of the median income - ILO) was respectively more $45 \%, 33 \% 14 \%$ [34]. In this are introduced regard the changes introduced in the Kazakhstan Tax code on individual income tax (IIT). Set the minimum bet at the pit taxable income up to 15 -times annual calculation index of $5 \%$ of the amount of taxable income and a maximum of 600 times the hydraulic fracturing and above the amount of tax of 600 -times the fracture $20 \%$ of the amount exceeding it (Surkova, Yu.V., 2017).

Introduced changes to vehicle tax aimed at the increase of income tax to local budgets, and the creation of conditions for the action of the regulatory functions of the transport tax. Rate is set at from 4 to 117 minimum calculated index (MCI), and provide for correction factors dependingfrom the service life of vehicles from1 to 0.1 (Vorontsova, V., Savdur, S., Fesina, E., \& Mustafin, A., 2019).

From 01.01.2002, the government places emphasis on fiscal and regulatory functions of the property tax. Installed the progressive rate of $0.05 \%$ of the value of the object of taxation to 1 million tenge, $05 \%$ of the value of the real estate to 23300 tenge $0,5 \%$ from the sum exceeding 10000000 tenge at the cost of the object of taxation excess of 10 million tenge.

In 2007, there is a transition of taxation IIT with a progressive scale of taxation at the flat rate of $10 \%$ and the taxation of income in the form of dividends received from sources in Kazakhstan at the rate of 5 percent. Previously, the minimum rate was 5\%, the annual income of the employee, taxable at the source of payment not exceeding 12 times the minimum wage, subject to taxation at the zero rate. This innovation appeared for the taxpayers by increasing the tax burden (Orekhovskaya, N. et al., 2016). The state pursued the goal of improving the legislation regarding the taxation of incomes of physical persons, incomes of the state budget and reduce the shadow income, smoothing income inequality of the population. The proportion of the population living below the poverty line in Kazakhstan in 2006 was $18.2 \%$, increased income inequality.

At the same time there is an improvement of the tax legislation developed and adopted a new edition of the Tax code dated 10 December 2008 №99-IV ZRK"About taxes and other obligatory payments to the budget (The tax code)", and from 01.01. 2009 comes into force. The main results of the reform of taxation in this period were the reduction of benefits and preferences, the gradual reduction of interest rates on the main taxes in the long run, optimization of tax statements (approach to international standards).

The third stage of the reform of taxation of natural persons between 2009 and 2019 is characterized by the following changes (table 9). 
Table 9. - Changes in taxation of natural persons in the RK in the 2009-2019 (Data from the Statistics Committee of the Ministry of National Economy, 2019)

\begin{tabular}{|c|c|c|}
\hline Period & Measures & Result \\
\hline 01.01 .2009 & $\begin{array}{l}\text { In } 2009 \text {, the concept of "Tax policy" was intro- } \\
\text { duced into the tax code of the RK. }\end{array}$ & Improving tax administration. \\
\hline 01.01 .2009 & $\begin{array}{l}\text { The basic rate of tax on adjoining land, is estab- } \\
\text { lished in size from } 0.2 \text { to } 6.0 \text { tenge per } 1 \text { sq.m }\end{array}$ & $\begin{array}{l}\text { Promotion rational use of the land for the in- } \\
\text { tended purpose, the achievement of fiscal, regu- } \\
\text { latory and stimulating balance. }\end{array}$ \\
\hline 01.01 .2009 & $\begin{array}{l}\text { Changes in the rates of property tax from } 0.05 \% \\
\text { at the cost of object of taxation of up to } 2 \text { million } \\
\text { tenge; } 0,5 \% \text { of the value of the real estate to } 23 \\
300 \text { tenge } 0,5 \% \text { from the sum exceeding } 10000 \\
000 \text { tenge at the cost of the object of taxation of } \\
\text { more than } 450 \text { million tenge }\end{array}$ & $\begin{array}{l}\text { Adjustment of rates of property tax in accord- } \\
\text { ance with the increase in the market value of the } \\
\text { property. } \\
\text { The implementation of fiscal and regulatory } \\
\text { functions of the property tax. The increase in } \\
\text { the tax burden of property owners. }\end{array}$ \\
\hline 01.01 .2009 & $\begin{array}{l}\text { Lower rates of tax on vehicles depending on the } \\
\text { engine capacity of passenger cars from } 1 \mathrm{MCI} \text { to } \\
1100 \mathrm{~cm} 3 \text { to } 9 \mathrm{MCI} \text { for } 4000 \mathrm{~cm} 3 \text {. Cancellation } \\
\text { correction factors for passenger cars in operation } \\
\text { for over } 6 \text { years. }\end{array}$ & $\begin{array}{l}\text { Stimulation the market for inexpensive cars, } \\
\text { focusing on the implementation of requirements } \\
\text { Implementation of regulatory, incentive and } \\
\text { environmental functions of tax. }\end{array}$ \\
\hline 01.01 .2014 & $\begin{array}{l}\text { Changes in the rates of vehicle tax depending on } \\
\text { engine capacity of passenger cars more than } \\
3000 \mathrm{~cm} 3 \text { from } 1 \text { to } 117 \mathrm{MCI} \text {. For manufactured or } \\
\text { imported into Kazakhstan after } 31.12 .2013 \text { - from } \\
35 \text { to } 200 \mathrm{MCI} \text { (Orynbassarova Y., Legostayeva } \\
\text { A., Omarova A., Ospanov, G. \& Grelo, M., } \\
\text { 2017). }\end{array}$ & $\begin{array}{l}\text { Improvement of the tax legislation. The increase } \\
\text { in budget revenues, the implementation of the } \\
\text { principles of social justice, the implementation } \\
\text { of regulatory and fiscal functions of the tax. }\end{array}$ \\
\hline $\begin{array}{l}01.09 .2014 \\
31.12 .2016\end{array}$ & $\begin{array}{l}\text { The introduction of a tax amnesty:exemption } \\
\text { from fines, penalties, outstanding on taxpayers } \\
\text { personal accounts. }\end{array}$ & $\begin{array}{l}\text { Improving of tax administration; the implemen- } \\
\text { tation of the principle of economy. }\end{array}$ \\
\hline 01.01 .2018 & $\begin{array}{l}\text { The expansion of the list of principles of Tax sys- } \\
\text { tem of Kazakhstan introduced the principle of } \\
\text { good faith of the taxpayer(State program of indus- } \\
\text { trial and innovative development of the Republic } \\
\text { of Kazakhstan for 2015-2019). }\end{array}$ & $\begin{array}{l}\text { The development of the theory of taxation. } \\
\text { Improving tax administration. }\end{array}$ \\
\hline 01.01 .2019 & $\begin{array}{l}\text { The increase in the minimum wage used in the } \\
\text { deductions in the calculation of IIT with } 28284 \\
\text { tenge in } 2018 \text { to } 42500 \text { tenge in } 2019 \text { [ } 41] \text {. Tax } \\
\text { exemption of } 90 \% \text { of the employee's income } \\
\text { when income is less than } 25 \mathrm{MCI} \text {, the rate reduc- } \\
\text { tion to } 1 \% \text { of assessed income(State program of } \\
\text { industrial and innovative development of the Re- } \\
\text { public of Kazakhstan for } 2015-2019 \text { ). }\end{array}$ & $\begin{array}{l}\text { Improvement of legislation in the part of IPN, } \\
\text { the implementation of the principle of fairness } \\
\text { of taxation, reducing the tax burden, providing } \\
\text { stimulating and regulating the functions of the } \\
\text { PIT(personal income tax). }\end{array}$ \\
\hline 01.01 .2019 & $\begin{array}{l}\text { Upper limit in the Tax code of RK defined in } \\
\text { MCI instead of RPMS. In the calculation of the } \\
\text { CCI: } \\
\text { - standard deduction in the amount of } 75 \text { times the } \\
\text { minimum wage is set at } 882 \text {-fold size of MCI (in } \\
2019 \text { - } 227050 \text { tenge);- tax deduction for medi- } \\
\text { cine in the amount not }>8 \text {-fold the minimum wage } \\
\text { is not }>94 \text {-fold size of MCI, for a particular calen- } \\
\text { dar year (in } 2019 \text { - KZT } 237350 \text { ). }\end{array}$ & $\begin{array}{l}\text { Changes in favor of the taxpayer, in } 2019, \mathrm{MW} \\
-42500 \text { tenge, MCI - } 2525 \text { tenge. By increas- } \\
\text { ing the multiplicity of MCI increased deduc- } \\
\text { tions. The implementation of the principle of } \\
\text { justice regulating the functions PIT, reducing } \\
\text { the amount of the annual income of a natural } \\
\text { person, which carries a PIT:indexation the limit } \\
\text { of non-taxable income. The redistribution of } \\
\text { budget funds to support socially not protected } \\
\text { layers of the population. }\end{array}$ \\
\hline 16.07.2019 & $\begin{array}{l}\text { Conducting a tax Amnesty for individuals to write } \\
\text { off penalties assessed for property tax, subject to } \\
\text { payment of the main debt on taxes before the end } \\
\text { of } 2019 \text {. }\end{array}$ & $\begin{array}{l}\text { Improvingtaxadministration; the implementation } \\
\text { of the principle of economy. }\end{array}$ \\
\hline
\end{tabular}

At this stage, the reform of the taxation of physical persons and the tax system of Kazakhstan is based on the established legislative framework. From the technology point of view reform is a must, able to ensure success 
in achieving the reform outcomes. Adopted new Tax code of RK, providing for the protection of the interests of bona fide taxpayer, the introduction of incentives and simplified administration. In this legislative framework still requires further improvements (Koksharov, V. Jamaibaly, B. Komissarov, O., 2019).

A positive point is the work of the state revenue Committee of IF (international fund) RK within the framework of "electronic government" on the improvement of tax administration using information technologies.

\section{Conclusion}

Given the success and mistakesto the reforming of the taxation of individuals in Russia and the Republic of Kazakhstan, the author has developed the proposed sequential algorithm for taxation reform (figure 1). Analysis of the system of taxation of physical persons should be carried out periodically and recorded in the working document of the Government, the Program of socio-economic development of the territories concerned.

Identified problems according to their importance and complexity are the basis for the decision about reform or addressing these issues programmatically.

Formulation and justification of objectives as the desired state of the system of taxation of individuals, vectors, transformations and development requires clear definition, quantification and feasibility.

\begin{tabular}{|c|}
$\begin{array}{c}\text { STEP I. Analysis of the system status of taxation of individuals: } \\
\text { identification of existing problems: decision-making holding on reform. }\end{array}$ \\
\hline STEP II. Justification aggregate clearly formulated, quantity of certain and implemented the objectives of the reform. \\
\hline $\begin{array}{r}\text { STEP III. Development of scenarios of development of the taxation of physical persons taking into account } \\
\text { the reform measures and changes in the environment in the long term, the choice of the best scenario. }\end{array}$ \\
$\begin{array}{r}\text { STEP IV. Development of a system to protect people from the negative effects of the reform } \\
\text { (minimum wage, tariffs for services of natural monopolies, the monetary policy instruments) }\end{array}$ \\
\hline STEP V. Socio-psychological, legal, personnel, organizational support reform. \\
\hline $\begin{array}{c}\text { STEP VI. Development of mechanisms to ensure the practical implementation of reforms } \\
\text { (administrative-legal, economic, political, social and other interventions). }\end{array}$ \\
\hline STEP VII. The definition spare options (waste routes) in case of failure.
\end{tabular}

Figure 1. The algorithm of the reform of taxation of natural persons

Note: Compiled by the authors

Develop scenarios (options for reform) is required due to the impact of internal and external factors and changes in the environment in the long term. To protect people from the negative impacts of reforms envisages a complex of measures in the area of indexation of prices and tariffs for services of natural monopolies, living wage, minimum wage, minimum wage, monetary policy (Potudanskaya, V.F., \& Alifer, E.O., 2016). Mandatory induction training of the population, by explaining through the media the objectives of the proposed reform, its implementation mechanisms and expected outcomes.

The legitimacy of the reform will ensure the development of a package of laws and regulations subject to the requirements of an integrated approach to neighboring objects. The new legal rules require appropriate training of professionals (seminars, trainings, courses) that will participate in the implementation of the reform measures and development of mechanisms for their implementation (Lobanova, T.N., 2015). In case of failure to prevent social conflicts provide for replacement options (waste way).

The proposed algorithm can serve as a universal tool for reforming how the entire tax system and its separate elements. It clearly shows that tax measures are not sufficient for sustainable economic growth. The necessary set of institutional and structural measures, the formation of the model of government that takes into account modern trends of development of society.

\section{References}

Agafonova, M.S., \& Chikisheva, E.Yu. (2017). Nematerialnoe stimulirovanie: blaho ili neobhodimost [Non-material incentives for benefits or necessity]. Nauchnometodicheskii electronnyi zhurnal - Scientific method. Journal, 171175 [in Russian].

Anatolevich, D., Grudina, S., Podgornaya, A., \& Avdonina, S. (2017). New technologies and their impact on the development of the labor market. Astra Salvensis. astrasalva.files.wordpress.com. Retrieved from https://astrasalva.files.wordpress.com/2018/01/astra-salvensis-supplement-no-1-2017.pdf

Artyuhova, I.V., \& Gavrilova, L.O. (2015). Metodika orhanizatsionnoho stimulirovania truda personala [Method of organization of stimulation of human needs]. Innovatsionnaia nauka - Innovative science, 76-78 [in Russian]. 
Ashirov, D.A. (2018). Trud: stimuly - motivy - motivatsia [Labor: incentives - motives - motivation]. Moscow: Moskovskii mezhdunarodnyi institut — Moscow: Moscow International institute [in Russian].

Bazarov, T.Y. (2010). Upravlenie personalom [Personnel management]. Moscow: Izdatelskii tsentr «Academia» Moscow: Publishing Center «Academy» [in Russian].

Baitenizov, D., Dubina, I., \& Azatbek, T. (2018). Trends of self-employment in Kazakhstan: Towards developed labor markets? Journal of Applied Economic Sciences, 13(8), 2216-2226.

Baitenizov, D.T., Dubina, I.N., Campbell, D.F.J., Carayannis, E.G., \& Azatbek, T.A. (2019). Freelance as a Creative Mode of Self-employment in a New Economy (a Literature Review). Journal of the Knowledge Economy, 10, 1.

Borbasova, Z.N., \& Bezler, O. (2018). Econometric assessment of factors of graduate employability. Journal of Applied Economic Sciences, 6(60), 1734-1739.

Borbasova, Z.N., Sedlarski, T., \& Bezler, O. (2019). Analysis of the modern interaction of the labor market and the professional education in Kazakhstan. Bulletin of the Karaganda University. Economy series, 1(93), 98-105.

Buhalkov, M.I. (2007). Organizacija i normirovanie truda, [Organization and regulation of the court]. Moscow: INFRA$M$ [in Russian].

Data from the Statistics Committee of the Ministry of National Economy (2019).

Kibanov, A.Y., Batkayeva, I.A., \& Mitrofanova, E.A. (2013). Upravlenye personalom: teoria i practika: uchebnopracticheskoe posobie, [Personnel management: theory and practice]. [in Russian].

Kibanov, A.Y., Batkayeva, I.A., Mitrofanova, E.A., \& Lovcheva, M.B. (2013). Motivatsia i stimulirovanie trudovoi deiatelnosti [Motivation and stimulation of work activities]. (Ed. A. Kibanova). Moscow: INFRA-M [in Russian].

Koksharov, V. Jamaibaly, B. Komissarov, O. (2019). The current state of economic development of the Republic of Kazakhstan and its prospects. Bulletin of Volgograd business institute Journal. Ser. Business. Education. Law, 4, $34-35$.

Lobanova, T.N. (2015). Motivatsia i stimulirovanie trudovoi deiatelnosti [Motivation and stimulation of labor activity]. [in Russian].

Malova, I.I. (2016). Sovremennye stratehii i kontseptsii sistem motivatsii i voznahrazhdeniia personala na osnove sbalansirovannoi sistemy pokazatelei [Modern strategies and concentrations with systems and rewards are personalized on the basis of a balanced system of indicators]. Menedzhment $v$ Rossii i za rubezhom - Management in Russia and abroad, 108-117 [in Russian].

Oganesyan, A.C., \& Oganesyan, I.A. (2012). Oplata truda rabotnikov [Salary of workers]. Menedzhment v Rossii i za rubezhom - Management in Russia and abroad, 90-92 [in Russian].

Orekhovskaya, N., Lavrentiev, S., Khairullina, E., Yevgrafova, O., Sakhipova, Z., Strakhova, I., Khlebnikova, N., \& Vishnevskaya, M. (2016). Management of young professionals success in the labor market. International Review Management and Marketing, 6, 2, 264-269.

Orynbassarova Y., Legostayeva A., Omarova A., Ospanov, G. \& Grelo, M. (2017). Razvitie finansovoi podderzhk1 innovatsionnoi deiatelnosti $v$ Respublike Kazakhstan [Development of financial support of innovative activity in the Republic of Kazakhstan]. Vestnik Karahandinskoho universiteta. Seriia Yekonomika - Bulletin of the Karaganda University. Economy series, 4(88), 224-231.

Potudanskaya, V.F., \& Alifer, E.O. (2016). Razvitie partisipativnogo upravlenya na promyshlennyh predpryatyah, [The development of parsipatic management in the fields]. Kreativnaja jekonomika - Creative economy, 2, 197210. DOI: $10.18334 /$ ce.10.2.35001 [in Russian].

Pritvorova, T., Tasbulatova, B., \& Petrenko, E. (2018). Possibilities of blitz-psychograms as a tool for human resource management in the supporting system of hardiness of company. Entrepreneurship and Sustainability Issues Journal. Retrieved from https://www.scopus.com/authid/detail.uri? authorId=55816012800

Skorobogatova, A., Khanmurzina, R., Tararina, L., Mirzagitova, A., Yakushevskiy, M., Sokolova, E., Faizrakhmanova A., \& Gainullina, R. (2016). Pedagogical managerial mechanisms of the labor market needs in a new generation of specialists. International Review Management and Marketing, 6, 2, $12-17$.

Shapiro, S.A., \& Shilayev, A.V. (2012). Faktory povysheniia effektivnosti truda personala. Moscow: ID «ATISO» [in Russian].

State program of industrial and innovative development of the Republic of Kazakhstan for 2015-2019. (2014). qazindustry.gov.kz Retrieved from https://qazindustry.gov.kz/docs/otchety/1650686.pdf

Surkova, Yu.V. (2017). Sistemnost nematerialnoho stimulirovaniia truda na predpriiatii [Factors to increase the efficiency of the use of information]. Human progress, 40-44 [ in Russian].

Tlesova, E. Zhanabaeva, Zh. (2019) The competitiveness of the economy as the most important factor in the economic security of Kazakhstan. Journal Economics and statistics, 2, 34-35.

Vorontsova, V., Savdur, S., Fesina, E., \& Mustafin, A. (2019). Pedagogical managerial mechanisms of the labor market needs in a new generation of specialists. International Journal of Supply Chain Management, 8, 4, 517-524. 


\section{Т.Л. Ищук, А.С. Баймухаметова \\ Ресей мен Қазақстан Республикасындағы жеке тұлғаларға салық салу реформаларының тарихи тәжірибесі}

Ацдатпа

Maқ̧cambl: Жеке тұлғалардың салық жүйесінің жай-күйін талдау және реформалау туралы шешім қабылдаудан бастап, қосалқы нұсқалардың айқындығына дейінгі іс-қимылдарға (кезеңдерге) негізделген қисынды дәйектілігін бағалау.

Әдістері: Мақаланы жазудың теориялық және әдіснамалық негізі шетелдік, ресейлік және қазақстандық ғалымдардың жеке тұлғаларға салық салу теориясы мен әдістемесі саласындағы жұмыстары болып табылады.

Қорытынды: Дағдарыстармен аяқталатын он жылдық циклдар шеңберіндегі 1991 жылдан 2020 жылға дейінгі Ресей, Қазақстан және басқа елдердің тәжірибесі негізінде жекелеген салық реформаларының шаралары мен нәтижелері, сондай-ақ реформалар, салық салу және экономиканы салықтық реттеу теорияларының ережелері арасындағы өзара байланыс анықталды. Мақалада реформаларды жүзеге асыру алгоритмі көрсетілген.

Тұжырымдама: Мақалада 1991 жылдан 2020 жылға дейінгі кезеңдегі жеке тұлғаларға салық салуды реформалау нәтижелері талданды. Ресей мен Қазақстан Республикасының мысалында салық салуды реформалау және экономиканы салықтық реттеу теорияларын ескере отырып, реформалардың кезеңділігіндегі заңдылықтар, салық салу теориясы, экономиканы салықтық реттеу және реформалар теориясы тұрғысынан оларды жүргізудегі сәттілік пен қателіктер анықталды. Салық жүйесінде, оның жеке элементтерінде реформалаудың әмбебап құралы бола алатын салық реформасын жүргізу алгоритмі ұсынылған. Бұл алгоритм мемлекеттік салық жүйесінің жеке ішкі жүйелерінде тұтастай алғанда салық жүйесін реформалаудың әмбебап құралы бола алады.

Кілm сөздер: салықтар, жеке тұлғаларға салық салу, жеке табыс салығы, табыс салығы, көлік салығы, жер салығы, жеке тұлғалардың мүлік салығы, салық реформалары.

\section{Т.Л. Ищук, А.С. Баймухаметова}

\section{Исторический опыт реформ налогообложения физических лиц в России и Республике Казахстан}

\section{Аннотация}

Цель: Оценить обоснованную логическую последовательность действий (этапов) от анализа состояния налоговой системы физических лиц и принятия решения о реформировании до определения запасных вариантов.

Meтоды: Теоретико-методологической основой написания данной статьи являются работы зарубежных, российских и казахстанских ученых в области теории и методологии налогообложения физических лиц.

Результаты: Выявлена взаимосвязь между мерами и результатами отдельных налоговых реформ на основе опыта России, Казахстана и других стран с 1991 по 2020 годы в рамках десятилетних циклов, заканчивающихся кризисами, а также положений теорий реформ, налогообложения и налогового регулирования экономики. В статье показан алгоритм реализации реформ.

Заключение: В статье проанализированы результаты реформирования налогообложения физических лиц за указанный выше период. На примере России и Республики Казахстан с учетом теорий реформирования налогообложения и налогового регулирования экономики выявлены закономерности в периодичности проведения реформ, удачи и ошибки в их проведении с точки зрения теории налогообложения, налогового регулирования экономики и теории реформ. Предложен алгоритм проведения реформы налогообложения, который может служить универсальным инструментом реформирования как всей налоговой системы, так и отдельных ее элементов. Кроме того, данный алгоритм может служить универсальным инструментом реформирования как отдельных подсистем государственной налоговой системы, так и налоговой системы в целом.

Ключевые слова: налоги, налогообложение физических лиц, НДФЛ, подоходный налог, транспортный налог, земельный налог, налог на имущество физических лиц, налоговые реформы.

\section{References}

Anatolevich D. New technologies and their impact on the development of the labor market / D. Anatolevich, S. Grudina, A. Podgornaya, S. Avdonina // Astra Salvensis. - 2017. — Vol. 1. — P. 385-390.

Baitenizov D. Trends of self-employment in Kazakhstan: Towards developed labor markets? / D. Baitenizov, I. Dubina, T. Azatbek // Journal of Applied Economic Sciences. — 2018. — № 3(8). — P. 2216-2226. (https://www2.scopus.com/authid/detail.uri? authorId=57208010069). 
Baitenizov D.T. Freelance as a Creative Mode of Self-employment in a New Economy (a Literature Review) / D.T. Baitenizov, I.N. Dubina, D.F.J. Campbell, E.G. Carayannis, T.A. Azatbek // Journal of the Knowledge Economy. - 2019. — Vol. 10, № 1. — (https://www2.scopus.com/authid/detail.uri? authorId=57208010069).

Borbasova Z.N. Econometric assessment of factors of graduate employability / Z.N. Borbasova, O. Bezler // Journal of Applied Economic Sciences. — 2018. — № 6(60). — P. 1734-1739. — (http://cesmaa.org/Docs/ JAES\%20Fall\%20Issue6(60)2018.pdf).

Borbasova Z.N. Analysis of the modern interaction of the labor market and the professional education in Kazakhstan / Z.N. Borbasova, T. Sedlarski, O. Bezler // Bulletin of the Karaganda University. Economy series. — 2019. — № 1(93). — P. 98-105. — (http://rep.ksu.kz//handle/data/7480)

Orekhovskaya N. Management of young professionals success in the labor market / N. Orekhovskaya, S. Lavrentiev, E. Khairullina, O. Yevgrafova, Z. Sakhipova, I. Strakhova, N. Khlebnikova, V. Vishnevskaya // International Review Management and Marketing. — 2016. — № 2. — P. 264-269.

Pritvorova, T. Possibilities of blitz-psychograms as a tool for human resource management in the supporting system of hardiness of company / T. Pritvorova, B. Tasbulatova, E. Petrenko // Entrepreneurship and Sustainability Issues Journal. — 2018. — № 6(2). — P. 840-853.

Skorobogatova A. Pedagogical managerial mechanisms of the labor market needs in a new generation of specialists / A. Skorobogatova, R. Khanmurzina, L. Tararina, A. Mirzagitova, M. Yakushevskiy, E. Sokolova, The system of stimulation of work in modern conditions Серия «Экономика». № 1(97)/2020 87 A. Faizrakhmanova, R. Gainullina // International Review Management and Marketing. — 2016. — Vol. 6, № 2. — P. $12-17$.

Vorontsova V. Pedagogical managerial mechanisms of the labor market needs in a new generation of specialists] / V. Vorontsova, S. Savdur, E. Fesina, A. Mustafin // International Journal of Supply Chain Management. — 2019. — Vol. 8, № 4. - P. 517-524.

Агафонова М.С. Нематериальное стимулирование благ или необходимость / М.С. Агафонова, Е.Ю. Чикишева // Науч.-метод. журн. - 2017. - № 4. - С. 171-175.

Артюхова И.В. Методика организационного стимулирования труда персонала / И.В. Артюхова, Л.О Гаврилова // Инновационная наука. - 2015. - № 7. - С. 76-78.

Аубакирова Г. Новые подходы к построению модели экономического роста Казахстана [Текст] / Г. Аубакирова // Экономические отношения. — 2019. — № 1. - С. 123-134.

Аширов Д.А. Труд: стимулы - мотивы - мотивация / Д.А. Аширов. - М.: Москов. междунар. ин-т, 2018. $262 \mathrm{c}$.

Базаров Т.Ы. Personnel Management / Т.Ы. Базаров. - М.: Изд. центр «Академия», 2010. — 224 с.

Бухалков М.И. Организация и нормирование труда [Текст] / М.И. Бухалков. - М.: ИНФРА-М, 2007. — 400 с.

Государственная программа индустриально-инновационного развития Республики Казахстан на 2015-2019 годы № 874 от 1 августа 2014 г. — (https:/qazindustry.gov.kz/docs/otchety/1650686.pdf).

Данные Статистического комитета Министерства национальной экономики. — (https://stat.gov.kz).

Кибанов А.Ы. Управление персоналом: теория и практика / А.Ы. Кибанов, И.А. Баткаева, Е.А. Митрофанова. М.: ИНФРА-М, 2013. - 64 c.

Кибанов А.Ы. Мотивация и стимулирование трудовой деятельности / А.Ы. Кибанов, И.А. Баткаыева, Е.А. Митрофанова, М.В. Ловчева. - М.: ИНФРА-М, 2013. — 224 с.

Кокшаров В. Современное состояние экономического развития Республики Казахстан и его перспективы [Текст] / В. Кокшаров, Б. Джаманбалин, О. Комиссарова // Вестн. Волгоград. ин-та бизнеса. Сер. Бизнес. Образование. Право. — 2019. - № 4(49). - С. 59-66.

Лобанова Т.Н. Мотивация и стимулирование трудовой деятельности / Т.Н. Лобанова. — М.: Юрайт, 2015. — $482 \mathrm{c}$.

Малова И.И. Современные стратегии и концепции систем мотивации и вознаграждения персонала на основе сбалансированной системы показателей / И.И. Малова // Менеджмент в России и за рубежом. - 2016. № 4. - С. 108-117.

Потуданская В.Ф. Развитие партисипативного управления на промышленных предприятиях / В.Ф. Потуданская, Е.О. Алифер // Креативная экономика. - 2016. - № 2. - С. 197-210.

Оганесян А.С. Оплата труда работников / А.С. Оганесян, И.А. Оганесян // Менеджмент в России и за рубежом. - 2012. — № 1. - С. 90-92.

Орынбасарова Е. Развитие финансовой поддержки инновационной деятельности в Республике Казахстан [Текст] / Е. Орынбасарова, А. Легостаева, А. Омарова, Г. Оспанов, М.Ф. Грело // Вестн. Караганд. ун-та. Сер. Экономика. — 2017. — № 4(88). - С. 224-231.

Суркова Ю.В. Системность нематериального стимулирования труда на предприятии / Ю.В. Суркова // Нuтап Progress. - 2017. - № 10. - C. 40-44.

Тлесова Э. Конкурентоспособность экономики как важнейший фактор экономической безопасности Казахстана [Текст] / Э. Тлесова, Ж. Жанабаева // Экономика и статистика. — 2019. — № 2. - С. 34-39.

Шапиро С.А. Факторы повышения эффективности труда персонала / С.А. Шапиро, А.В. Шилаев. - М.: ИД «АТИСО», 2012. - 222 с. 